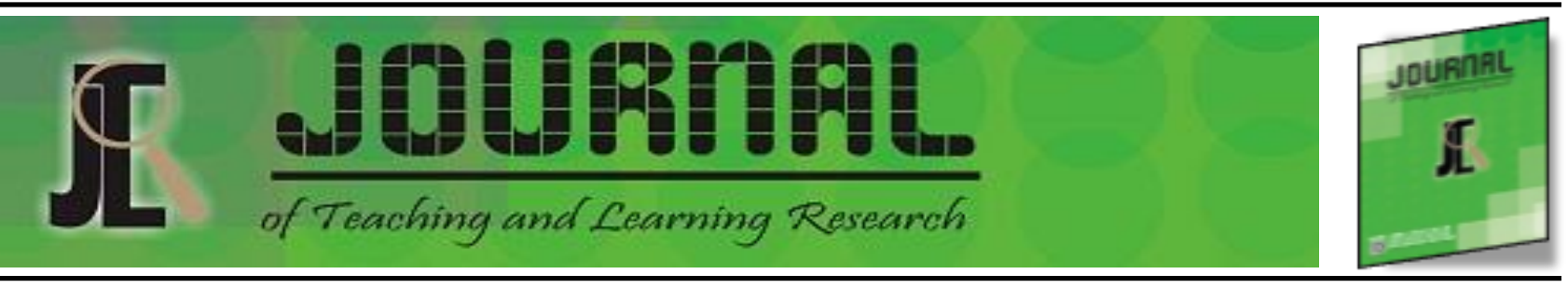

\title{
Peranan Model Pembelajaran Kooperatif Tipe Scramble Terhadap Minat Belajar Peserta Didik Pada Mata Pelajaran IPS Di Kelas III SD Islam Datok Sulaiman Palopo
}

\author{
Kartila \\ Institut Agama Islam Neger Palopo \\ kartilatila9@gmail.com
}

\begin{abstract}
This study aims to determine the implementation of scramble type cooperative learning models and to find out the learning interests of students who apply the model and to know the supporting factors and obstacles to the implementation of scramble type cooperative learning models in increasing student interest in social studies in Grade III Islamic Elementary School Datok Sulaiman Palopo. This study uses a type of qualitative descriptive research carried out in class III Islamic Elementary School Datok Sulaiman Palop. Data collection techniques used were observation, interviews, and documentation. The results of this study indicate that the implementation of a scramble type cooperative model makes students directly active in learning activities.
\end{abstract}

Keywords: Model Pembelajaran Kooperatif Tipe Scramble, Minat Belajar

\section{A. Pendahuluan}

Pendidikan berfungsi membantu peserta didik dalam pengembangan dirinya, yaitu pengembangan semua potensi, kecakapan, serta karakteristik pribadinya ke arah yang positif, baik bagi dirinya maupun lingkungannya (Nana Syaodih Sukmadinata, 2009:4). Menurut teori naturalisme romantik dari Jean Jacques Rousseau (Rusman, 2014:386) memandang bahwa individu memiliki potensi-potensi atau kemampuan-kemampuan yang masih terpendam dan 
memiliki kekuatan sendiri untuk mengembangkan dirinya secara mandiri. Usaha membentuk kecakapan dalam diri peserta didik guna mencapai tujuan pendidikan, perlu peningkatan kinerja guru sebagai tenaga pengajar (Edhy Rustan dan Muh. Said Bahru, 2018:2). Guru yang profesional diyakini mampu memotivasi peserta didik dan mengoptimalkan potensinya dalam kerangka pencapaian standar pendidikan yang ditetapkan (Syaiful Sagala, 2013:41). Dengan begitu diharapkan guru dapat melahirkan peserta didik yang cerdas dan berakhlak mulia.

Peserta didik adalah subjek dari sebuah pendidikan dan oleh sebab itu menjadi pokok permasalahan dari seluruh proses pendidikan yang berlangsung di sekolah (Basilius R. Werang, 2015:37). Guru berperan aktif dalam mengembangkan potensi peserta didik dan bertanggung jawab penuh untuk mewujudkan tujuan pembelajaran. Guru yang profesional adalah guru yang dapat melakukan tugas mengajarnya dengan baik (Zainal Aqib, 2015:84). Guru memiliki banyak tugas baik yang terkait dengan tugas formal maupun tugas nonformal dalam bentuk pengabdian (Syamsu S, 2017:5). Paling sedikit ada enam tugas dan tanggung jawab guru dalam mengembangkan profesinya, yakni bertugas sebagai pengajar, pembimbing, administrator kelas, pengembang kurikulum, mengembangkan profesinya, dan membina hubungan dengan masyarakat (Udin Syaefuddin Saud, 2013:32). Melalui pengembangan profesi keguruan maka tujuan pendidikan dapat terlaksana dengan baik.

Proses pembelajaran peserta didik dapat dipengaruhi oleh beberapa faktor, salah satu faktor di antaranya adalah minat belajar. Menurut Sukardi (Ahmad Susanto, 2013:57) bahwa minat dapat diartikan sebagai suatu kesukaan, kegemaran, atau kesenangan akan sesuatu. Adapun menurut Sardiman (Ahmad Susanto, 2013:57) bahwa minat adalah suatu kondisi yang terjadi apabila seseorang melihat ciri-ciri atau arti sementara situasi yang dihubungkan dengan keinginan-keinginan atau kebutuhan-kebutuhan sendiri. Oleh sebab itu, minat merupakan dorongan dalam diri seseorang atau faktor yang menimbulkan ketertarikan atau perhatian secara efektif, yang menyebabkan dipilihnya suatu objek atau kegiatan yang menguntungkan, menyenangkan, dan lama kelamaan akan mendatangkan kepuasan dalam dirinya (Ahmad Susanto, 2013:58). Maksudnya, jika seseorang memiliki kebutuhan atau keinginan terhadap sesuatu maka tentunya akan muncul rasa dorongan atau minat untuk memilikinya.

Belajar merupakan aktivitas yang dilakukan seseorang untuk mendapatkan perubahan dalam dirinya melalui pelatihan-pelatihan atau pengalaman-pengalaman (Baharuddin dan Esa Nur Wahyuni, 2010:12). Pertumbuhan, kematangan, dan perkembangan merupakan proses yang saling berkaitan dan keduanya merupakan perubahan yang berasal dari dalam diri anak (M. Asrori, 2015:17). Belajar merupakan salah satu usaha yang dapat dilakukan peserta didik untuk meraih perubahan baik dari segi kognitif, afektif dan psikomotorik. Maksudnya perubahan tidak hanya berkaitan dengan penambahan ilmu pengetahuan, tetapi juga berbentuk kecakapan, keterampilan, sikap, pengertian, harga diri, minat, watak, dan penyesuaian diri (Sardiman A.M, 2011:21). Dengan demikian, minat belajar adalah suatu ekspresi yang menunjukkan adanya ketertarikan dan partisipasi peserta didik melalui pikiran, 
perasaan dan tindakan terhadap suatu objek yang dipilih sehingga dapat memberikan suatu kepuasan dan kesenangan dalam dirinya saat mengikuti kegiatan pembelajaran.

Setiap peserta didik tentunya memiliki minat yang berbeda-beda terhadap suatu mata pelajaran. Adanya perbedaan tersebut, tentunya guru harus dapat memahaminya. Mengelola perbedaan artinya menggali dan mengidentifikasi berbagai keunikan masing-masing, kemudian dibagi dan disalurkan sehingga terjadi interaksi yang saling membutuhkan satu dengan lainnya (Muhammad Yaumi, 2013:118-119). Oleh sebab itu, pentingnya pemahaman guru terhadap karakteristik dari setiap peserta didik.

Minat dapat diekspresikan melalui suatu pernyataan yang menunjukkan bahwa peserta didik lebih menyukai suatu hal daripada hal lainnya, dapat pula dimanifestasikan melalui partisipasi dalam suatu aktivitas (Slameto, 2013:180). Minat belajar yang besar cenderung menghasilkan prestasi yang tinggi, sebaliknya minat belajar yang kurang akan menghasilkan prestasi yang rendah (M. Dalyono, 2012:57). Oleh sebab itu, guru perlu melakukan cara yang efektif untuk menumbuhkan minat belajar peserta didik terhadap pembelajaran yang akan diberikan.

Pembelajaran yang efektif adalah apabila pelajar-pelajar melakukan perilaku secara aktif (Lefudin, 2014:17). Guru dalam hal ini harus kreatif mengolah pembelajaran dengan menggunakan metode dan model yang sesuai dengan jenis mata pelajaran yang akan diberikan. Menurut Joyce (Agus Suprij ono 214:46) bahwa melalui model pembelajaran guru dapat membantu peserta didik mendapatkan informasi, ide, keterampilan, cara berpikir, dan mengekspresikan ide. Dengan demikian, peran model pembelajaran menjadi salah satu faktor yang menentukan keberhasilan guru dalam melaksanakan kegiatan pembelajaran.

Memilih model pembelajaran sangat dipengaruhi oleh sifat dari materi yang akan diajarkan, dan juga dipengaruhi oleh sifat dari materi yang akan diajarkan, dan juga dipengaruhi oleh tujuan yang akan dicapai dalam pengajaran tersebut serta tingkat kemampuan peserta didik (Darmadi, 2017:42). Menurut teori Vigotsky (C. Asri Budiningsih, 2015:107) menyatakan bahwa dalam kegiatan pembelajaran hendaknya anak memperoleh kesempatan yang luas untuk mengembangkan zona perkembangan proximalnya atau potensinya melalui belajar dan berkembang. Oleh sebab itu, di dalam menentukan model pembelajaran yang akan diterapkan guru harus memiliki pemahaman yang baik tentang peserta didik, keragaman kemampuan, motivasi, minat, dan karakteristik pribadi lainnya (Syamsu S, 2015:74). Dengan memahami segala perbedaan dari kemampuan dan karakteristik peserta didik, maka guru dapat menentukan model pembelajaran mana yang sesuai dengan kebutuhan dan kondisi peserta didik.

Diketahui dari hasil ulangan harian peserta didik kelas III A SD Islam Datok Sulaiman Palopo yang sebagian besar masih belum mencapai kriteria ketuntasan minimal (KKM) yang telah ditetapkan yakni 65. Dari 30 peserta didik hanya 25\% (12 peserta didik) yang sudah mencapai KKM, sedangkan 75\% (18 peserta didik) belum mencapai KKM. Upaya yang dapat dilakukan guru untuk mengatasi permasalahan tersebut adalah dengan memberikan model 
pembelajaran yang bersifat permainan. Model pembelajaran kooperatif tipe scramble adalah salah satu model pembelajaran yang dapat digunakan pada mata pelajaran Ilmu Pengetahuan Sosial (IPS).

Menurut Rober B. Taylor (Miftahul Huda, 2015:303), bahwa scramble merupakan salah satu metode pembelajaran yang dapat meningkatkan konsentrasi dan kecepatan berpikir peserta didik. Menurut Wulandari (Sholihatin Fitriyah dan Sondang S, 2014:12), bahwa scramble merupakan permainan menyusun kembali susunan huruf-huruf yang memang telah dikacau balaukan terlebih dahulu menjadi kata seperti semula. Adapun menurut Suyatno (Metta Ariyanto, 2016:135), bahwa scramble adalah suatu metode pembelajaran yang menggunakan kartu soal dan kartu jawaban yang dipasangkan atau diurutkan menjadi urutan logis. Dengan demikian, dapat disimpulkan bahwa scramble adalah model pembelajaran yang dikerjakan secara berkelompok dalam menerka dan menyusun jawaban soal yang tersedia secara acak untuk membentuk kata yang logis.

Semua metode pembelajaran kooperatif menyumbangkan ide bahwa peserta didik bekerja sama dalam belajar dan bertanggung jawab terhadap teman satu timnya mampu membuat diri mereka belajar sama baiknya (Robert E. Salvin, 2015:10). Dengan bekerja sama, anggota kelompok kecil dapat mengatasi berbagai ritangan, penuh tanggung jawab, mengandalkan bakat setiap anggota kelompok, memercayai orang lain, mengeluarkan pendapat, dan mengambil keputusan (Elaine B. Johnson, 2009:164). Oleh sebab itu, terdapat banyak keuntungan apabila model pembelajaran scramble diterapkan terhadap peserta didik.

Adapun langkah-langkah model pembelajaran kooperatif tipe scramble adalah: (1) Guru menyajikan materi sesuai kompetensi yang ingin dicapai; (2) Guru membagikan lembar kerja sesuai contoh; (3) Susunlah huruf-huruf pada kolom B sehingga merupakan kata kunci (jawaban) dari pertanyaan pada kolom A (Miftahul Huda, 2015:305-306). Berdasarkan langkah-langkah tersebut guru diharapkan dapat menyusun soal dan jawaban dengan sesuai materi pembelajaran yang hendak diberikan kepada peserta didik. Menurut Bruner (C. Asri Budiningsih, 2015:42) bahwa perkembangan kognitif seseorang dapat ditingkatkan dengan cara menyusun materi pelajaran dan menyajikannya sesuai dengan tahap perkembangan orang tersebut. Oleh sebab itu, model pembelajaran kooperatif tipe scramble, sangat cocok bagi peserta didik kelas rendah.

Berdasarkan uraian tersebut peneliti melakukan penelitian dengan mengkaji model pembelajaran kooperatif tipe scramble sebagai salah satu model pembelajaran yang digunakan di SD/MI, dengan tujuan untuk : 1) Mengetahui pelaksanaan model pembelajaran kooperatif tipe scramble pada mata pelajaran IPS di kelas III SD Islam Datok Sulaiman Palopo. 2) Mengetahui minat belajar peserta didik yang menerapkan model pembelajaran kooperatif tipe scramble pada mata pelajaran IPS di kelas III SD Islam Datok Sulaiman Palopo. 3) Mengetahui faktor pendukung dan penghambat pelaksanaan model pembelajaran kooperatif tipe scramble dalam meningkatkan minat belajar peserta didik di kelas III SD Islam Datok Sulaiman Palopo 


\section{B. Metode Penelitian}

Jenis penelitian yang digunakan adalah penelitian deskriptif kualitatif. Penelitian ini bertujuan untuk mendeskripsikan informasi tentang status gejala dari objek penelitian dalam bentuk narasi. Penelitian ini dilaksanakan di SD Islam Datok Sulaiman yang beralamat di Jl. Puang H. Daud No. 05 Palo po. Sumber data pada penelitian ini adalah guru dan peserta didik kelas III A SD Islam Datok Sulaiman Palopo.Subjek penelitian ini adalah peserta didik kelas III A SD Islam Datok Sulaiman Palopo dengan jumlah 32 peserta didik.

Adapun teknik pengumpulan data pada penelitian ini adalah wawancara, observasi, dan dokumentasi. Analisis data pada penelitian ini menggunakan model Miles dan Huberman, yakni meliputi reduksi data, penyajian data dan verifikasi/penarikan kesimpulan. Teknik keabsahan data pada penelitian ini menggunakan dua cara yakni: 1) perpanjangan pengamatan dalam hal ini peneliti melakukan kembali penelitian ke SD Islam Datok Sulaiman Palopo untuk mengamati dan melakukan wawancara terhadap guru dan peserta didik guna mendapatkan informasi yang lebih lengkap. 2) Peningkatan ketekunan dimaksudkan bahwa peneliti melakukan pengamatan secara lebih cermat dan berkesinambungan agar kepastian data dan urutan peristiwa dapat dipercaya 


\section{Hasil Penelitian}

1. Pelaksanaan Model Pembelajaran Kooperatif Tipe Scramble pada Mata Pelajaran IPS

Adapun untuk mengatahui bagaimana pelaksanaan model pembelajaran kooperatif tipe scramble pada mata pelajaran IPS, berikut peneliti telah menguraikan hasil penelitian yang diperoleh dilapangan.

a. Guru menyajikan materi tentang mengenal lingkungan alam dan buatan

Tujuan pembelajaran yang diharapkan adalah peserta didik dapat mengidentifikasi contoh lingkungan alam dan buatan, dapat memahami kegunaan lingkungan alam dan buatan bagi manusia, dan dapat memahami cara merawat lingkungan alam dan buatan. Menurut Rachman S.Pd.I jika peserta didik sudah senang dan nyaman dengan gurunya maka apapun yang diajarkan gurunya pasti mereka akan memerhatikan pelajaran tersebut. Oleh sebab itu, guru menjadi kunci utama dalam mengolah materi ajar agar peserta didik dapat tertarik dalam mengikuti pembelajaran.

\section{b. Guru membentuk kelompok diskusi}

Pembentukan kelompok dilakukan saat guru telah selesai menyajikan materi tentang pembelajaran. Setiap kelompok beranggotakan 4-5 orang yang disesuaikan dengan jumlah peserta didik dalam satu kelas. Setelah pembagian kelompok telah selesai maka guru pun menjelaskan kepada peserta didik tentang aturan dalam mengerjakan soal secara berkelompok.

c. Guru membagikan lembar kerja soal dan jawaban

Saat peserta didik telah memahami aturan dalam mengerjakan soal maka guru pun membagikan lembar kerja soal dan jawaban. Dalam proses pembelajaran maka setiap anggota kelompok akan saling berdiskusi dan bekerja sama dalam menyusun huruf yang diacak menjadi kata yang sempurna dan logis sesuai dengan pertanyaannya. Setiap kelompok berlomba-lomba mengerjakan soal yang diberikan. Adapun guru memantau dan menilai setiap kelompok dalam menyelesaikan soal. Jika waktu pengerjaan soal sudah habis, setiap kelompok wajib mengumpulkan lembar soal dan jawaban kepada guru.

d. Guru menilai hasil kerja peserta didik

Guru melakukan penilaian terhadap hasil kerja peserta didik dengan berdasarkan seberapa cepatsetiap kelompok menyelesaikan soal dan berapa soalyang dikerjakan dengan benar. Bagi kelompok yang berhasil menyelesaikan soal dengan cepat dan benar maka guru memberikan apresiasi baik dalam bentuk ucapan selamat ataupun pemberian hadiah.

2. Minat Belajar Peserta Didik yang Menerapkan Model Pembelajaran Kooperatif Tipe Scramble pada Mata Pelajaran IPS

Adapun minat belajar peserta didik yang menerapkan model pembelajaran kooperatif tipe scramble pada mata pelajaran IPS di kelas III SD Islam Datok Sulaiman Palopo mengalami peningkatan. Hal tersebut dapat dilihat dari indikator minat belajar peserta didik yang berbeda dengan keadaan sebelumnya.

a. Peserta didik menjadi lebih senang/suka terhadap mata pelajaran IPS 
Melalui model pembelajaran kooperatif tipe scramble membuat peserta didik lebih bersemangat dalam mengikuti pembelajaran. Menurut Rachman S.Pd.I bahwa peserta didik senang jika diberikan games karena dapat merasa nyaman saat mengikuti pembelajaran". Dengan berlomba-lomba menyusun huruf yang telah diacak membuat kegiatan pembelajaran menjadi seru dan menyenangkan.

b. Peserta didik menjadi lebih tertarik dalam mempelajari IPS

Apabila peserta didik telah senang dan suka terhadap pembelajaran IPS maka secara otomatis rasa ketertarikan pun akan muncul dengan sendirinya. Menurut Rachman S.Pd.I bahwa rasa ketertarikan peserta didik muncul karena merasakan kenyamanan saat belajar IPS dengan cara yang berbeda dengan biasanya. Dengan demikian, peserta didik menganggap bahwa belajar IPS ternyata juga asyik dan menyenangkan.

c. Adanya partisipasi peserta didik dalam kegiatan pembelajaran IPS

Menurut Rachman S.Pd.I bahwa partisipasi dari setiap anggota kelompok dapat terihat pada saat pengerjaan soal, dimana setiap anggota kelompok saling bekerja sama dan saling membantu satu sama lain untuk menyelesaikan tugas dengan cepat dan benar. Oleh sebab itu, model pembelajaran kooperatif tipe scramble membuat hubungan diantara peserta didik menjadi lebih akrab.

d. Adanya perhatian peserta didik pada pembelajaran IPS

Menurut Rachman S.Pd.I, bahwa dengan model pembelajaran scramble membuat peserta didik menjadi lebih bersemangat dalam mengikuti pembelajaran IPS, hal tersebut terlihat pada raut wajah berseri dan gerak aktif peserta didik dalam menyusun huruf dengan cepat dan tepat. Oleh sebab itu, dengan suasana pembelajaran yang menyenangkan secara otomatis dapat menarik perhatian peserta didik untuk mengikuti kegiatan pembelajaran.

3. Faktor Pendukung dan Penghambat Pelaksanaan Model Pembelajaran Kooperatif Tipe Scramble dalam Meningkatkan Minat Belajar Peserta Didik pada Mata Pelajaran IPS

Pelaksanaan kegiatan pembelajaran tentunya dipengaruhi oleh faktor yang mendukung dan menghambat proses pelaksanaannya. Hal tersebut bisa dilihat dari aspek teknis berupa sarana dan prasarana sekolah dan aspek non teknis berupa kemampuan guru dalam mengolah pembelajaran dan bagaimana kondisi peserta didik saat mengikuti pembelajaran. Berikut adalh uraian dari faktor pendukung dan penghambat yang memengaruhi pembelajaran scramble.

a. Faktor Pendukung Pelaksanaan Model Pembelajaran Kooperatif Tipe Scramble dalam Meningkatkan Minat Belajar Peserta Didik pada Mata Pelajaran IPS

1) Guru memberikan motivasi kepada peserta didik

Pemberian motivasi kepada peserta didik dapat memberikan dampak positif terhadap kesiapan jiwa peserta didik dalam mengawali pembelajaran. Sebab dengan begitu, peserta didik diharapkan dapat mengikuti pembelajaran dengan hati yang senang dan ikhlas.

2) Guru membagi kelompok secara heterogen 
Pembagian kelompok yang dilakukan guru secara heterogen dimaksudkan untuk menghindari adanya kemampuan yang tidak merata dari setiap kelompok. Dengan pembagian secara heterogen maka setiap kelompok memiliki kemampuan yang relatif sama.

3) Pemberian pemahaman tentang tujuan pembagian kelompok

Pemberian pemahaman kepada peserta didik tentang tujuan pembagian kelompok adalah sesuatu yang harus dilakukan guru. Dengan memberi pemahaman kepada peserta didik dapat membuat mereka paham dengan tanggung jawabnya di dalam kelompok.

4) Pemberian apresiasi kepada peserta didik

Pemberian apresiasi dapat membuat peserta didik merasa dihargai atas usaha yang telah dilakukan. Dengan demikian, peserta didik pun akan bertambah semangat dalam mengikuti pembelajaran.

b. Faktor Pendukung Pelaksanaan Model Pembelajaran Kooperatif Tipe Scramble dalam Meningkatkan Minat Belajar Peserta Didik pada Mata Pelajaran IPS

1) Terbatasnya pemahaman guru terhadap peserta didik

Guru sebagai tokoh utama yang berperan penting dalam memahami kondisi peserta didik haruslah sigap dalam merespon apa yang menjadi permasalahan pada peserta didik. Guru harus mengetahui setiap perkembangan peserta didik dalam merespon suatu pembelajaran.

2) Penggunaan model pembelajaran yang monoton

Ada banyak jenis model pembelajaran yang dapat diterapkan guru dalam melaksanakan kegiatan pembelajaran salah satunya adalah model pembelajaran kooperatif tipe scramble. Namun, guru tidak mesti menggunakan model scramble secara terus-menerus sebab hal tersebut akan membuat peserta didik menjadi bosan dan jenuh. Oleh sebab itu, penggunaan dari berbagai model pembelajaran dimaksudkan agar pembelajaran menjadi lebih bermakna dan lebih bervariasi serta tidak menimbulkan kejenuhan pada peserta didik.

3) Kemampuan belajar peserta didik yang rendah

Guru tentunya menginginkan semua peserta didik dapat mengikuti pembelajaran dengan baik. Namun, tak dipungkiri kemampuan dari setiap peserta didik itu berbeda-beda, ada yang tingkat kecerdasannya di atas, standar dan bahkan ada yang tingkat kecerdasannya di bawah. Dengan demikian, hal itu pula yang dapat menghambat jalannya kegiatan pembelajaran.

\section{E. Pembahasan}

Berdasarkan hasil penelitian terhadap pelaksanaan model pembelajaran kooperatif tipe scramble pada mata pelajaran Ilmu Pengetahuan Sosial (IPS) di Kelas III SD Islam Datok Sulaiman Palopo diketahui bahwa aktivitas belajar peserta didik menjadi lebih bervariasi dan lebih bermakna. Melalui model pembelajaran kooperatif tipe scramble membuat peserta didik ikut terlibat langsung dalam kegiatan pembelajaran. Akibatnya adalah dapat memberikan pengaruh positif bagi perkembangan kognitif, psikomotorik dan afektif peserta didik. MenurutBruner (C. Asri Budiningsih, 2015:42) mengatakan bahwa perkembangan kognitif seseorang dapat ditingkatkan dengan cara 
menyusun materi pelajaran dan menyajikannya sesuai dengan tahap perkembangan orang tersebut. Oleh sebab itu, model pembelajaran kooperatif tipe scramble sangat cocok bagi anak usia kelas rendah untuk memahami materi dengan mudah.

Menurut teori naturalisme romantik dari Jean Jacques Rousseau (Rusman, 2014:386) memandang bahwa individu memiliki potensi-potensi atau kemampuan-kemampuan yang masih terpendam dan memiliki kekuatan sendiri untuk mengembangkan dirinya secara mandiri. Menurut teori Vigotsky (C. Asri Budiningsih, 2015:107) mengatakan bahwa dalam kegiatan pembelajaran hendaknya anak memperoleh kesempatan yang luas untuk mengembangkan zona perkembangan proximalnya atau potensinya melalui belajar dan berkembang. Dengan memberi kesempatan kepada peserta didik untuk mengembangkan potensinya maka peserta didik dapat belajar secara mandiri dalam menemukan dan memahami suatu objek dengan cara yang alami.

Berdasarkan hasil penelitian terdapat pula faktor pendukung dan penghambat yang memengaruhi proses pelaksanaan model pembelajaran kooperatif tipe scramble. Pada faktor pendukung pelaksanaan model pembelajaran scramble tentunya dapat membantu dalam membuat pembelajaran lebih efektif. Sedangkan faktor penghambat pelaksanaan model pembelajaran scramble biasanya berasal dari guru, peserta didik, ataupun fasilitas sekolah. Oleh sebab itu, semua aspek harus terus ditingkatkan untuk mewujudkan pembelajaran yang lebih baik.

\section{F. Penutup}

Pelaksanaan model kooperatif tipe scramble pada mata pelajaran Ilmu Pengetahuan Sosial (IPS) di kelas III SD Islam Datok Sulaiman Palopo memberikan perubahan positif terhadap aktivitas belajar peserta didik. Melalui model pembelajaran kooperatif tipe scramble peserta didik dapat belajar dengan aktif dan menyenangkan. Adapun minat belajar peserta didik yang menerapkan model pembelajaran kooperatif tipe scramble ini mengalami peningkatan. Sebab, diketahui dari indikator minat belajar peserta didik terjadi perubahan positif dari tingkah laku belajar peserta didik selama mengikuti pembelajaran. Diantaranya adalah munculnya perasaan senang peserta didik terhadap mata pelajaran Ilmu Pengetahuan Sosial (IPS), yang kemudian menarik perhatian peserta didik untuk turut berpartisipasi dalam melaksanakan tugas kelompok dengan baik. Faktor pendukung dan penghambat pelaksanaan model pembelajaran kooperatif tipe scramble dalam meningkatkan minat belajar peserta didik di kelas III SD Islam Datok Sulaiman Palopo dapat diketahui berdasarkan aspek teknis berupa sarana dan prasarana dan non teknis berupa kemampuan guru dan kondisi peserta didik yang memengaruhinya.

\section{BIBLIOGRAPHY}

Ariyanto, Metta "Peningkatan Hasil Belajar IPA Materi Kenampakan Rupa Bumi Menggunakan Model Scramble.” Jurnal Profesi Pendidikan Dasar, Vol 3 No. 2 (Desember, 2016). 
Asrori, M, Perkembangan Peserta Didik (Pengembangan Kompetensi Pedagogik Guru, Cet. I; Yogyakarta, 2015.

Aqib, Zainal, Model-Model, Media, dan Strategi Pembelajaran Kontekstual (Inovatif), Cet. V; Bandung: Yrama Widya, 2015.

Baharuddin \& Esa Nur Wahyuni, Teori Belajar dan Pembelajaran, Cet.V; Jogjakarta: Ar-Ruzz Media, 2010.

Budiningsih, C. Asri, Belajar dan Pembelajaran, Cet. II; Jakarta: Rineka Cipta, 2015.

Dalyono, M, Psikologi Pendidikan, Cet. VII; Jakarta: Rineka Cipta, 2012.

Darmadi, Pengembangan Model Metode Pembelajaran dalam Dinamika Belajar Siswa, Cet. I; Yogyakarta: Deepublish, 2017.

Huda, Miftahul, Model-model Pengajaran dan Pembelajaran: Isu-isu Metodis dan Pragmatis, Cet. VI; Yogyakarta: Pustaka Pelajar, 2015.

Johnson, Elaine B., Contextual Teaching dan Learning, Cet. VIII; Bandung: MLC, 2009.

Lefudin, Belajar dan Pembelajaran, Cet. I; Yogyakarta: Deepublish, 2014.

Rusman, Model-Model Pembelajaran (Mengembangkan Profesionalisme Guru), Cet. V; Jakarta: Rajawali Pers, 2014.

Rustan, Edhy dan Muh. Said Bahru, "Penguatan Self Confidence dalam Pembelajaran Matematika melalui Metode Suggestopedia." Jurnal Pendidikan Matematika dan Ilmu Pengetahuan Alam, Vol. 6. No. 1 (2018).

S, Sholihatin Fitriyah dan Meini Sondang, "Pengaruh Permainan Scramble dalam Model Pembelajaran Kooperatif Tipe TGT terhadap Hasil Belajar pada Mata Pelajaran Teknik Elektronika Dasar di SMK Negeri 1 Kediri." Jurnal Pendidikan Teknik Elektro, Vol. 3 No. 3 (2014).

S, Syamsu, Strategi Pembelajaran (Meningkatkan Kompetensi Guru), Cet. I; Makassar: Penerbit Aksara Timur, 2015.

S, Syamsu, Strategi Pembelajaran (Tinjauan Teoritis Praktis Bagi Mahasiswa dan Praktisi Pendidikan), Cet. I; Makassar: Nas Media Pustaka, 2017.

Sagala, Syaiful, Kemampuan Profesional Guru dan Tenaga Kependidikan, Cet. IV; Bandung: 2013.

Sardiman, Interaksi dan Motivasi Belajar Mengajar, Cet. XX, Jakarta: Rajawali Pers, 2011.

Saud, Udin Syaefuddin, Pengembangan Profesi Guru, Cet. VI; Bandung: Alfabeta, 2013.

Slameto, Belajar dan Faktor-faktor yang Mempengaruhi, Cet. VI; Jakarta: Rineka Cipta, 2013.

Slavin Robert E., Cooperrative Learning (Teori, Riset, dan Praktik), Cet. XV; Bandung: Nusa Media, 2015.

Sukmadinata, Nana Syaodih, Landasan Psikologi Proses Pendidikan, Bandung: Remaja Rosdakarya, 2009.

Suprijono, Agus, Cooperative Learning, Cet. XIII; Yogyakarta: Pustaka Pelajar, 2014.

Susanto, Ahmad, Teori Belajar dan Pembelajaran di Sekolah Dasar, Cet. II; Jakarta: Kencana, 2013. 
Werang, Basilius R., Manajemen Pendidikan di Sekolah, Cet. I; Yogyakarta: Media Akademi, 2015.

Yaumi, Muhammad, Prinsip-Prinsip Desain Pembelajaran, Cet. II; Jakarta: Fajar Interpratama Mandiri, 2013 